\title{
Clinical and Experimental Aspects of Viral Myocarditis
}

\author{
KEVIN LESLIE, ROY BLAY, CARL HAISCH, ANN LODGE, ANN WELLER, AND SALLY HUBER* \\ Department of Pathology, University of Vermont, Burlington, Vermont 05405
}

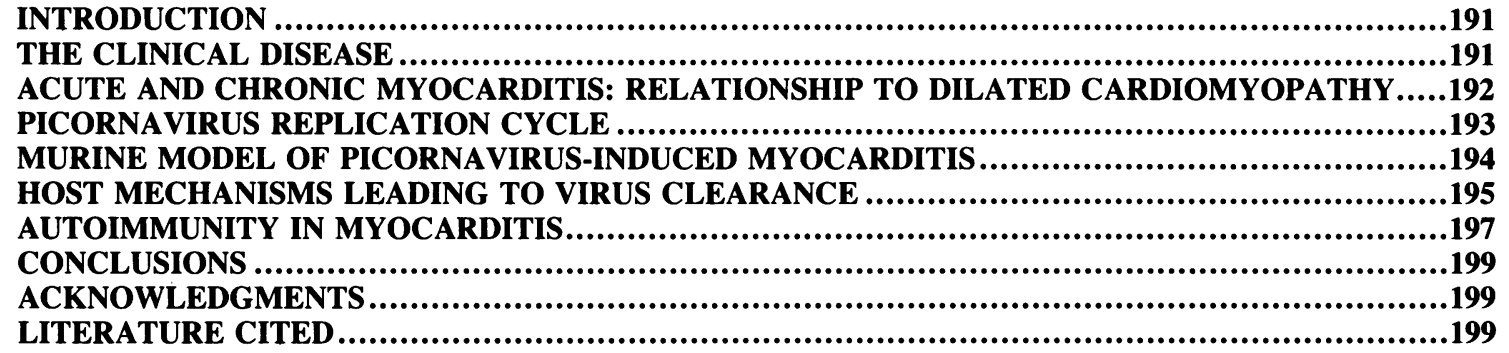

\section{INTRODUCTION}

In the second half of the 19th century, all cases of nonvalvular heart disease were termed myocarditis (140). Currently, myocarditis is defined as inflammatory infiltration of the muscular layer of the heart associated with myocyte injury, which does not resemble ischemic infarction (4). This definition attempts to exclude a variety of conditions in which lymphoid cells may be observed in the heart without specifically causing myocardial injury. In active myocarditis, cardiac injury is a direct consequence of inflammatory cells entering the heart, and these mononuclear cells must be in intimate contact with areas of damage (4). Adjacent portions of the same myofiber bundles may appear normal. This is in contrast to other conditions such as malignancy, ischemia, or trauma, in which lymphoid cells may be present in the myocardium either without causing myocyte damage or only to remove tissue destroyed by other mechanisms. Because so many conditions mimic myocarditis, estimates of this disease at autopsy, which range from 1 to $4 \%(123,144)$, are undoubtedly inaccurate.

Myocarditis can have both infectious and noninfectious etiologies. Hypersensitivity reactions, along with chemical and drug toxicities, account for the preponderance of these etiologies, especially when alcohol and adriamycin cardiomyopathy are included. Among cardiovascular diseases initiated by known infectious agents, Chagas' disease caused by Trypanosoma cruzi clearly ranks worldwide as the major and most serious form (Public Health Laboratory Service Report, Memorandum, Br. Med. J. 4:575-577, 1967). This disease rarely occurs outside of South America, however, except through emigration of infected individuals prior to onset of cardiac symptoms. Rheumatic heart disease (27) and Lyme disease (134) are both examples of inflammatory heart disease initiated by microbial infection. While the incidence of the former illness is rapidly decreasing in much of the industrialized world, that of the latter, a recently identified syndrome initiated through spirochete infection, is expanding.

Today, most cases of myocarditis in the United States and Europe, when an etiological agent can be determined, result from a variety of viral infections (147). Many viruses have been implicated in myocarditis (147), but the principal agents belong to the picornavirus family $(36,39,124,136,139,147)$.

\footnotetext{
* Corresponding author.
}

This virus group (poliovirus, coxsackievirus, echovirus, and rhinovirus) was discovered as a by-product of the intensive study of poliovirus infection during the 1940s. Successful isolation of specific viruses in primary human myocarditis has been principally confined to coxsackieviruses $(39,138$, $139)$ and other picornaviruses $(66,100)$, and it is now generally accepted that coxsackievirus B (CVB), types 1 to 5 , is the predominant cause of human viral myocarditis (77). In this review, we will examine the role of coxsackieviruses in human myocarditis and present clinical and experimental data regarding the pathogenicity of these cardiotropic microorganisms. Furthermore, we will present evidence in support of the hypothesis that this cardiotropism has serious implications with respect to the development of chronic inflammatory heart disease and cardiac failure (cardiomyopathy).

\section{THE CLINICAL DISEASE}

The principal clinical symptom of myocarditis is chest pain (131). This complaint may be supported by electrocardiographic changes consisting of sinus tachycardia, ST-T segment abnormalities, and ventricular conduction disturbances (147). Critical to the diagnostic consideration of myocarditis in any patient is the absence of preexisting cardiac disease (99). The clinical presentation is somewhat dependent on the age of the patient. Infants may show tachycardia, inactivity, and pyrexia during the acute phase of the disease. There may be nonspecific electrocardiographic findings and evidence for multiorgan involvement (147). In adults, initial chest pain may be accompanied or followed by symptoms of pericarditis (147). Acute sequelae, although rare, include coronary artery occlusion, rapidly progressive heart failure, and sudden death (147). Other signs of the acute disease include tachycardia, murmurs, arrhythmias, rales, and cardiomegaly. Electrocardiogram changes in adults include ST-T wave abnormalities, conduction disturbances, and Q-wave abnormalities (1, 147). Unfortunately, such dramatic clinical findings are not always present. To emphasize this point, even when chronic myocarditis is identified histologically, in many cases an acute phase of the disease cannot be identified historically by the patient or physician. It is likely that the majority of individuals with acute myocarditis experience no more than a mild flulike illness with nonspecific symptoms and vague clinical signs of heart disease (107). 
The endomyocardial biopsy (EMB) has become the major definitive diagnostic tool in the pathologic confirmation of clinical myocarditis. Thirty years ago, the procedures for EMB were technically difficult and associated with considerable morbidity (143). These procedures varied from open thoracic surgery to percutaneous core biopsy of the myocardium, and all required violation of the pericardial space. Intramural hemorrhagic complications, pneumothorax, and pleuritic pain were common untoward events, and if one good tissue sample was obtained, the procedure was considered successful. In 1962, Sakakibara and Konno reported on a new transvenous EMB technique using the Konno bioptome (121). Unlike its predecessors, the transvenous biopsy method produced minimal morbidity and allowed the performance of multiple biopsies. This technique is in use today, although the bioptome has been improved over the years. Currently, EMB is performed safely and frequently in the management of heart transplant recipients and can be used in the evaluation of primary myocardial diseases (35). As this practical biopsy technique has been applied to the diagnosis of myocarditis, important new considerations have been encountered. These include biopsy artifacts, limitations in sampling, and wide variability in pathologic interpretation. These considerations, along with new morphologic data concerning this disease derived from the biopsy technique, have led to the establishment of a working formulation for the morphologic diagnosis of myocarditis (4). The diagnostic criteria in this formulation were assembled in Dallas, Tex. by a group of cardiovascular pathologists participating in a large multicenter clinical trial evaluating therapeutic alternatives for the treatment of active myocarditis. Known as the "Dallas criteria," these were designed to provide a reproducible basis for making a pathologic diagnosis of active myocarditis and have become the focus of considerable discussion and controversy. The principal criticism has revolved around the requirement for both lymphocytic infiltration and morphologic evidence of myocyte necrosis to establish unequivocal myocarditis. There is evidence that a considerable number of patients with symptoms and signs characteristic of myocarditis do not fulfill all of these requirements upon biopsy (95). In humans, persistent inflammatory cell infiltrates in the heart have been observed histologically in patients recovering from well-documented acute viral myocarditis (11). Conversely, lymphocytic infiltration of the heart was identified in $87 \%$ of 108 patients dying with cardiomyopathy by Billingham and Tazaalar (11) and in $63 \%$ of 35 patients evaluated by EMB for unexplained heart failure by Zee-Cheng et al. (150). Objective histologic evidence for myocyte necrosis in these studies is atypical The exact reason for this phenomenon is unknown but may be related to the limited sample size of the biopsies or may be indicative of low sensitivity of morphologic assessment alone in this diagnosis. Regarding the latter point, other diagnostic modalities have been evaluated recently in the diagnosis of myocarditis. These include radioisotopic scans of the heart, using gallium-67 citrate (108) and indium111-labeled monoclonal antibodies to myosin (149). Indeed, these noninvasive techniques may prove to be an important part of the total assessment of myocarditis in conjunction with other clinical and laboratory diagnostic methods.

Three commonly used laboratory methods are available to implicate virus as a cause of myocarditis in patients presenting with symptoms and signs suggestive of this disease (76, 147). First, and most common, antibody response to a specific virus can be documented by using the patient's serum. This method requires paired sera obtained during acute and convalescent phases of the infection to detect a minimum of a fourfold rise in antiviral antibody titer (16). Determination of immunoglobulin subclass may allow distinction of acute (jmmunoglobulin $\mathrm{M}$ [IgM]) versus chronic (IgG) antibody response to the virus (125). If only serum specimen is available, this distinction may be helpful in associating a single positive viral titer with a recent clinical episode suggestive of myocarditis. Second, virus can be isolated if tissues or fluid specimens are obtained during the acute phase of infection and inoculated into an appropriate medium, usually specific types of cells in culture, embryonated avian eggs, or susceptible animals. Appropriate specimens include pharyngeal swabs, serum, and feces. Once virus replication begins in these media, a characteristic colony morphology or cytolysis can be demonstrated. This type of assay depends on the virus producing a specific type of reaction; used alone, it may not distinguish among virus families. Finally, if a tissue sample is obtained, a search can be made for morphologic characteristics of the virus in infected cells (16). Examples are the Cowdry type A inclusions of the herpesvirus group (96) and the cytoplasmic inclusions seen in certain brain cells of individuals infected with rhabdovirus (rabies). Furthermore, specific probes for viral antigens or nucleic acid sequences may be applied to tissue sections by using in situ techniques for probe visualization (i.e., immunocytochemistry and in situ nucleic acid hybridization) $(12,14,23)$. Unfortunately, morphologic, virologic, and serologic evidence to support a viral etiology of myocarditis is found less often than this disease is suspected clinically (10). In summary, the symptoms of myocarditis may be nonspecific, and even when present, a viral etiology cannot be established in every case. These inherent difficulties in studying the human disease have led to greater emphasis on studies that use experimental animals to model the disease and provide data regarding pathogenetic mechanisms.

\section{ACUTE AND CHRONIC MYOCARDITIS: RELATIONSHIP TO DILATED CARDIOMYOPATHY}

Subacute and chronic inflammatory heart disease can be seen in patients months to years after acute viral myocarditis. The chronic disease is manifested pathologically by the presence of interstitial cardiac fibrosis, with or without inflammation, myocardial hypertrophy, and chamber dilation as the heart fails (1). The clinical manifestations are those of progressive congestive heart failure and have been termed cardiomyopathy. The incidence of dilated cardiomyopathy in the United States is estimated at 10 per 100,000 population per year (147), but no good estimates are available to indicate the number of patients whose disease was caused by viral agents. Congestive heart failure may have many causes and represents the end stage of several distinct and unrelated diseases. Thus, only a fraction of myocarditis patients ultimately progress to cardiomyopathy, and myocarditis-associated cardiomyopathy represents only a fraction of the total population developing congestive heart failure.

As emphasized earlier, one of the major problems with identifying the evolution of myocarditis to dilated cardiomyopathy is that, in most patients, the symptoms of the acute disease may be nonspecific and mild, obviating the possibility of early diagnostic studies. Furthermore, careful examination of the heart and detailed historical evaluation fail to implicate a viral etiology in the majority of patients suffering from or dying with cardiomyopathy. For this reason, most of 
our knowledge about the natural history of viral myocarditis has been derived from anecdotal case reports and a relatively small number of published series of cases involving highly selected patients (106).

Kline and Saphir documented progressive myocardial failure in 29 patients months to years after acute myocarditis (74). Several studies have documented persistent and progressive symptoms, along with chest X-ray and electrocardiogram abnormalities, following acute viral myocarditis (predominately coxsackieviruses) $(8,50,120,131,132)$. Miklozek et al. followed 16 patients diagnosed as having viral myocarditis by using serial cardiac function tests. They found that $75 \%$ of these individuals had one or more abnormal tests during the course of their study (99). Abelmann examined cardiac function in patients with diagnosed myocarditis (1). Patients were accepted for serial study only after other possible causes of cardiac decompensation were excluded. As part of the evaluation, a Holter monitor was used to monitor heart function continuously. Intraventricular conduction defects, atrioventricular block, frequent premature ventricular or atrial beats, and supraventricular tachycardia were documented. Viral studies included culture and a search for antibodies directed against cytomegalovirus and Epstein-Barr virus. Some $44 \%$ of patients had cardiac symptoms, and $63 \%$ had an abnormal physical exam over the course of follow-up. The overall conclusion was that persistent cardiac dysfunction is not unusual after recovery from the acute viral illness. Ayuthya et al. studied 50 consecutive patients with dilated cardiomyopathy and found significantly higher incidences and levels of neutralizing antibodies to coxsackieviruses in these patients than in controls (5). Recent work by Bowles et al. (12) and Kandolf et al. (67) has shown CVB-specific nucleic acid sequences in the heart tissue of patients with active or healing myocarditis as well as in a smaller number of patients with dilated cardiomyopathy. Unfortunately, these studies primarily serve to demonstrate the possibility that viral infections lead to cardiomyopathy rather than defining the susceptibility factors (such as specific virus types or a particular genetic predisposition of the host) which determine who will develop cardiomyopathy.

\section{PICORNAVIRUS REPLICATION CYCLE}

Morphologic assessment of tissue obtained at autopsy or by EMB reveals some common morphologic changes in myocarditis and cardiomyopathy $(91,107)$. From these studies, and from available data on experimental viral myocarditis, the following disease sequence can be deduced. Since picornaviruses constitute the predominant etiological agents in human viral myocarditis $(135,145)$, the sections that follow will deal with these viruses.

Picornaviruses are small, nonenveloped viruses containing a single-stranded ribonucleic acid (RNA) of positive sense. The genome comprises approximately $30 \%$ of the molecular mass of the virus and is enclosed within an icosahedral protein capsid. The capsid consists of 60 protomers made up of equal numbers of four proteins designated VP1 through VP4. Antigenic sites for virus neutralization involve portions of each of these proteins. The surface of the protein capsid is irregular, with depressions resembling "canyons" which may hold the receptor sites required for binding to cell surface molecules. Furthermore, the rim of the canyon may be responsible for interactions with antibodies (81). Virus usually enters the host by oralfecal transmission and establishes localized centers of virus replication. Nonspecific host defenses influence this process (69). Enteric viruses must be resistant to low $\mathrm{pH}$, proteolytic enzymes, and the detergent action of bile salts to establish an infection. Following multiplication and release of virions into the circulation, viremia develops, seeding the infectious agents in selected tissues (69).

Host specificity and tissue tropism have long been hallmarks of viral infections. Polioviruses, rhinoviruses, coxsackieviruses, and encephalomyocarditis (EMC) virus are typically human pathogens, while cardioviruses and apthoviruses infect mice and cloven-footed animals, respectively (115). In addition to a specific host range, viruses have an affinity for particular tissues (115). Well-known examples include the growth of poliovirus in the anterior horn cells of the spinal cord, coxsackievirus tropism for skeletal and cardiac muscle, and the replication of rhinovirus in the nasopharynx. Preliminary evidence in our laboratory indicates that endothelial cells derived from different tissues show distinct susceptibilities to CVB type 3 (CVB3) infections (Huber, unpublished observations). If true, endothelial cells may form the initial "gateway" to infection of an organ. Several factors are involved in determining tropism. Probably the most important of these is the presence of specific viral receptors on the host cell $(18,130)$. These receptors are not well characterized, but probably are glycoproteins having molecular weights ranging from $5 \times 10^{4}$ to $9 \times 10^{4}$. Picornaviruses have high mutation rates, with variants differing in pathogenicity, infection, and replication characteristics such as interferon induction and plaque size, antigenicity (97), and receptor recognition (19, 54). Different variants may utilize distinct cellular receptors on the same cell or may distinguish between cell types, thus resulting in specific organ tropism. The number and location of virus receptors may differ between cell types and may vary depending on cell differentiation. Thus, tissues highly susceptible to picornavirus infection in neonatal or fetal periods may lose receptors in later life (115).

Following virus attachment, the next critical step in virus infection involves internalization of the virion through a process termed viroplexy. Attachment alone is insufficient to explain virus entry. Schultz and Crowell described a nonfusing myogenic cell line which expressed receptors for group A coxsackievirus but which was incapable of internalizing bound virus (128). Other fusable myogenic cell lines were permissive and allowed virus replication. These observations suggest that characteristics of membrane fluidity and cytoskeletal elements may affect internalization of the virus. Rearrangements of the virus capsid occur soon after adsorption and result in loss of VP4, increased sensitivity to proteases and detergents, and loss of infectivity (22).

The mechanism of entry into the cell varies among picornaviruses. Poliovirus is internalized by receptor-mediated endocytosis, while internalization of rhinovirus and EMC virus proceeds by other endocytic pathways $(87,151)$. Receptor-mediated endocytosis involves the clustering of virus-receptor complexes in clathrin-coated pits which invaginate to form coated vesicles. Vesicles uncoat and fuse with intracellular vesicles to form endosomes. The endosomes containing virus particles may then fuse with lysosomes or the Golgi apparatus or directly release virus into the cytoplasm (151). The uncoating of poliovirus and rhinovirus appears to require low $\mathrm{pH}$, suggesting degradation of the capsid within lysosomes or endosomes $(87,151)$ while uncoating of EMC is not dependent on low pH (86). Studies by Roesing et al. have demonstrated that an isolated plasma membrane fraction is capable of binding, rearrangement, and 
uncoating of CVB3, suggesting that the receptor itself is responsible for releasing the viral genome (118).

Once virus is taken up by the cell into the cytoplasm, the genome acts as a messenger RNA for synthesis of virus proteins. One of the more interesting aspects of virus infections is the ability of the virus to interfere with and inhibit host protein synthesis, converting the cell into a viral "factory." The mechanism by which this event is accomplished is not completely understood but seems to function through gradual dissociation of the polysome complexes normally observed in the host cell cytoplasm, with ultimate reaggregation into considerably larger (350S) and more homogeneous polysomes which make virus polypeptides exclusively (6). Since cellular messenger RNA remains in the cytoplasm and appears unaltered, virus-mediated inhibition of host protein synthesis probably occurs at the level of translational initiation. The precise mechanisms involved in this process are now being elucidated and apparently differ depending on the virus and the type of cell infected (64). In the case of poliovirus-infected HeLa cells, cap-binding protein complex is inactivated, thus preventing translation of capped host messenger RNA while allowing translation of uncapped viral RNA (31). Inhibition of protein synthesis occurs later in infection and gradually declines. Concurrent synthesis of cellular and viral proteins is seen throughout infection, but the viral portion of total synthesis increases (63). These data suggest that EMC RNA simply competes for the factors necessary for translation. However, EMC infection of $\mathrm{L}$ cells results in a rapid shutoff of host translation which may proceed by yet another mechanism (64). Other theories attribute protein synthesis inhibition to the toxic effects of coat protein, inactivation of factors for initiation, and accumulation of double-stranded RNA (115).

RNA synthesis is also inhibited during picornavirus infection. Studies of cell-free transcription in extracts of poliovirus-infected HeLa cells indicate that a factor required for transcription by polymerase II is deficient in infected cells (17). A viral protein may be responsible for this defect since treatment of cells with puromycin prevents inhibition of RNA synthesis (7).

Picornaviruses require a host cell factor for synthesis of viral RNA (115). Cells lacking the appropriate factor fail to produce functional progeny virions and infection is aborted even through viral receptor is expressed. Such infections still result in significant alterations in the host cell. Shutoff of deoxyribonucleic acid synthesis is probably secondary to alterations in RNA and protein syntheses. Cytopathic effects of picornavirus infection include increased plasma membrane permeability, presumably mediated through alterations in membrane composition. Intracellular components leak from the cytoplasm and the cell shrivels. Disintegration of the cell is probably due to the combined effects of inhibition of macromolecular synthesis and accumulation of virus and structural proteins (115). In the experimental animal heart, myocytolysis is attended morphologically by coagulative cytoplasmic contraction and granularity, nuclear pyknosis, and cell fragmentation (54).

Whether cell death represents the only mechanism of virus release is unclear. During the last several years, in vitro studies have demonstrated persistent virus infections lasting many months and even years (126). These infections may result from low-grade lytic infections in which only a small percentage of cells are susceptible to infection at any one time. Replication of the remaining uninfected cells would replace those killed by the virus. The culture as a whole would remain persistently infected, although infection would continue to be lethal for individual cells. In vivo, organ function may suffer when the number of remaining cells decreases below a certain threshold level. The alternative explanation to cell death must assume that picornaviruses initiate long-term, nonlethal infections with either continuous or intermittent virus shedding. How a nonenveloped virus replicating in the cytoplasm exits the cell without killing it remains to be determined. Possibly, progeny viruses enter the endosomal pathway and leave through exocytosis. Virus replication in this case would presumably be less efficient than in a lytic infection, and cellular protein synthesis might be decreased but not eliminated. Thus, infected cells may be functionally defective. In vivo, cell number within an organ may not decrease, but the organ function would be compromised. Other studies have demonstrated persistence of the virus genome in tissues without evidence of infectious virus production (12). As with nonlytic infections releasing functional virions, this situation may also lead to dysfunctional, but viable cells. Presumably, mutations may lead to defects in virus protein translation and assembly without affecting genome transcription.

\section{MURINE MODEL OF PICORNAVIRUS-INDUCED MYOCARDITIS}

Although many viruses are associated with clinical myocarditis, relatively few have been used to establish animal models. These include reoviruses in mice (45), parvoviruses in dogs (98), and picornaviruses in various species such as primates $(79)$, hamsters, and rodents $(21,71,73)$. The murine model of picornavirus-induced myocarditis is the most extensively studied. All of the CVBs (types 1 to 5) can induce some degree of myocarditis in mice, but different patterns of disease are seen. Grodums and Dempster (48) found that types 1 and 5 CVB produced myocarditis in suckling mice, but types 2,3 , and 4 were minimally myocarditic in this age group. On the other hand, all five types produced myocarditis in adult animals. Type 3 virus (both the Nancy strain and a second isolate) produces extensive cardiac lesions in weanling and adult animals. Variants of CVB3 have been produced which replicate in the heart but are not myocarditic $(37,38,110)$. In humans, variant CVB4 with different tissue tropisms can be isolated from the same person and are antigenically distinguishable from each other with monoclonal, but not polyclonal, antisera (113).

The myocardial lesions observed in mouse hearts following CVB3 infection closely resemble those of the acute disease in humans $(44,47,48,51,52,72,92,109,114,118 \mathrm{a})$. Scattered necrotic foci are found throughout the ventricles and, to a lesser extent, in the atria. The pericardium and endocardium are rarely involved. A primary lesion consists of necrotic muscle fibers with pycnotic or absent nuclei, surrounded by mononuclear cells. Adjacent areas of the myocardium appear intact. Lesions may also occur around blood vessels and often involve periarteritis. Later, fibers are replaced with connective tissue or calcification or both, and the number of mononuclear cells diminishes $(47,51)$. In strains of mice which are susceptible only to acute myocarditis (B strains [51], BALB/c [60], and CD-1 [145]), the process described above resolves in 1 to 2 weeks. In strains susceptible to chronic disease (Swiss mice [145] and A strains [51, 118a]), inflammation continues after day 7 , with lesions becoming calcified and quite large. Inflammatory cells within the lesions are abundant, with macrophages comprising approximately $50 \%$ of the mononuclear cells in lesions during the early phase of infection (92) and the remainder of 
the infiltrate consisting of lymphocytes and fibroblasts. The lymphocytic component contains natural killer cells, CD4 and CD8 T cells, and B cells or plasmacytes. While numbers of both T-cell subsets increase during the acute disease, CD8 cell infiltration rapidly outpaces that of the CD4 cells. After 21 to 45 days, early foci become fibrotic and new inflammatory lesions develop. Plasmacytes and B cells are more numerous during this phase (78).

A variety of mechanisms may be involved in myocyte injury after CVB3 infection. As indicated above, virus infection alone can induce significant cardiocyte alterations, and this form of injury may be substantially increased under certain conditions that enhance virus replication. Administration of cortisone to CVB3-infected mice completely blocks the inflammatory response in the heart, yet extensive fiber necrosis still occurs (146). Heart viral titers from cortisone-treated animals were found to be 4 to 5 logs higher than titers from hearts of animals infected in the absence of cortisone, despite equivalent amounts of circulating virusneutralizing antibody in the two groups. This finding suggests that cardiac damage results solely from the cytolytic properties of the virus. The same pattern is seen in mice treated with anti-asialo $\mathrm{GM}_{1}$ to decrease natural killer cell activity (41). This treatment also increases heart viral concentration 2 to 4 logs, and necrosis is extensive despite decreased inflammation. Other researchers have reported similar findings in animals that are immunosuppressed by dietary deprivation, exercise, and hypothermia $(41,117)$. All of these conditions, however, are characterized by uncontrolled viral replication.

Under more normal conditions, it seems unlikely that the bulk of cardiac injury induced by CVB3 infection results from host responses to infection. CVB3-infected BALB/c mice depleted of $T$ lymphocytes have heart virus titers equivalent to those of nonimmunocompromised infected controls, yet develop minimal myocarditis $(57,148)$. Severe pathologic changes in the heart are rarely seen before day 5 postinfection, when lymphocytic infiltration begins and the viral titer is dropping rapidly $(43,62,78,147)$. Inflammation and damage may continue for days or weeks after virus can no longer be detected. Also, light and electron microscopic studies have revealed that necrotic cardiocytes are surrounded by infiltrates comprised primarily of macrophages, $\mathrm{T}$ cells, and relatively few B cells (42). Whether lymphocytic effector cells directly mediate tissue injury or only produce lymphokines activating other inflammatory cells which actually lyse cardiocytes is not known. However, some circumstantial evidence favors the hypothesis that macrophages participate in lesion formation since activated rat macrophages have receptors for $L$-mannosyl or $L$-fucosyl residues $(129,133)$ and murine heart tissues infected with a myocarditic variant of CVB3 express L-fucosyl residues as detected by lectin binding (82).

\section{HOST MECHANISMS LEADING TO VIRUS CLEARANCE}

The natural result of infection is the induction of various cellular and humoral immune responses to virus antigens designed to eliminate the infectious agent before serious harm occurs. The interactions between the virus and myocardium, and between the host defense mechanisms and virus, are best illustrated in defined murine models of coxsackievirus-induced myocarditis. Coxsackieviruses can be found in the heart within $3 \mathrm{~h}$ of intraperitoneal inoculation, and viral replication in heart and other target organs is well established within $24 \mathrm{~h}(62,85)$. Viral concentrations peak 3 to 4 days postinfection, after which time host immune mechanisms become activated and the virus is rapidly eliminated. Inflammatory cell infiltrates consisting of macrophages and lymphocytes first appear around day 5 (148).

In vivo, alterations in cardiocytes can be detected by electron microscopy shortly after infection. Changes in nuclei include coarsened chromatin, enlarged nucleoli, and an increased number of nuclear pores (114). By day 3 of infection, viral titers are at their highest level, but inflammatory cells are not yet present. Myofibers show disruption of myofilaments and mitochondria, as well as further degenerative changes in nuclei. Virus clearance is, in part, accomplished by neutralizing antibody directed to attachment epitopes on the virus that interfere with the interaction between the virion and the cell surface receptor. Rising titers of virus-specific IgM antibodies correlate with decreasing viral titers, since they appear 2 days after infection and peak at day 4. Virus-specific IgG is observed initially on day 6 and peaks at day $14(62,78)$. Complete protection from CVB3 infection and myocarditis can be achieved by administration of virus-neutralizing antibody to mice either shortly before or after virus inoculation (116). Production of early-arising IgM antibodies is apparently not dependent on $\mathrm{T}$ cells, as this process is unaffected in T-cell-depleted mice during the first week $(15,148)$. Similarly, coxsackieviral infection is readily cleared in nude mice (49). However, antibody response at later time points is depressed in the presence of antithymocyte serum (146), suggesting that T-helper cells are absolutely required for IgG responses and, therefore, contribute to long-term humoral immunity.

Virus-neutralizing antibodies are not the only factors acting in defense against coxsackieviral infection. Macrophages comprise the greatest percentage of the mononuclear infiltrate in the heart 5 to 10 days postinfection $(42,146,148)$, and they appear to work in conjunction with circulating antibodies to limit the spread of virus. When macrophages are prevented from entering the heart by cortisone treatment, CVB3-induced cardiac damage is severe and organ virus titers remain elevated despite normal levels of circulating antiviral antibody (146). Administration of either immune serum or adult peritoneal exudate cells protects suckling mice from infection, showing that either host factor can influence virus replication. However, when suboptimal concentrations of peritoneal cells and antibody are simultaneously administered, protection is greatly enhanced (46, 47). Similar evidence implicates interferon and natural killer (NK) cells in controlling picornavirus infections. NK cell activity was observed to be at a maximum 3 days after infection, correlating with peak virus titers (41). Mice depleted of NK cells with anti-asialo $\mathrm{GM}_{1}$ antiserum exhibited increased virus titers in the heart and more severe myocarditis; thus, it appears that NK cells function to limit virus replication, which in turn decreases the severity of myocarditis even though NK cell activity does not correlate with the presence or absence of myocarditis (41). There is also evidence that large, granular, activated splenic lymphocytes taken from CVB3-infected mice 3 days postinfection are capable of limiting CVB3 replication both in vitro and in vivo by killing virus-infected cells (43). Interferon stimulates NK cells, activates macrophages, and prevents infection of healthy cells $(41,68)$. As inbred mouse strains differ in their capacities for both interferon production and NK cell activity, these factors could contribute to the observed differences in response to coxsackieviral infection among different strains $(37,51)$. 
Cellular immunity may take several forms. While NK cells can distinguish in a general manner between infected and uninfected cells (resulting in lysis of the former), $T$ cells are antigen specific and respond to unique attributes of the different viruses. During infection, virus or virus-antibody complexes or both are phagocytized by monocytic cells and reduced to peptide fragments within lysosomes. Specific fragments (antigenic epitopes) are transported to the cell membrane and become physically associated with major histocompatibility complex (MHC) antigens either in the transport vesicles or directly on the plasma membrane (40). Presentation of viral epitopes in this format stimulates $\mathrm{T}$ cells with appropriate receptors for these peptides. When peptides interact with class II MHC antigens, CD4 T cells respond, while antigens presented on class I MHC antigens stimulate CD8 cells. These T-cell subsets were previously known as "T helper" and "T cytolytic" cells, respectively. More recent studies show that T-cell function cannot be so easily divided. Helper and cytolytic cells can belong to either T-cell population $(24,33,141)$.

Both the cytolytic T lymphocyte (CTL) and the NK cell can interrupt the virus replication cycle by lysing infected cells before many progeny virions are produced (43). With CTL, this assumes that specific virus epitopes must be appropriately expressed in conjunction with MHC antigens on the infected target cell membrane. Virus-specific antigens cannot be identified on infected cells by immunofluorescence, complement-mediated and antibody-dependent cellmediated cytotoxicity assays that use antiserum reacting to virus in either neutralization, or enzyme-linked immunoadsorption assays $(56,62)$. These results indicate that the epitopes recognized by the humoral immune response do not appear on coxsackievirus-infected cells. Indeed, at an earlier time, one might have questioned how a nonbudding virus could place virus-specific antigens on the plasma membranes of infected cells. Recently, extensive and elegant studies by two groups of workers have greatly advanced conceptualization of antigen processing and presentation in virus-infected cells.

Townsend and Braciale and their respective colleagues have now demonstrated two pathways of influenza virus antigen processing in infected cells $(80,101,138)$. The first involves the peptides released during uncoating of the viral genome in lysosomal vesicles. These peptides are ultimately transported back to the plasma membrane and released into the extracellular space. During transit, these molecules may become associated with class II MHC antigens which are in rich supply on endosomal membranes. Once on the plasma membrane, the peptide-MHC complex can either stimulate CD4 T-cell responses or act as target antigens for lysis of the infected cell by CTL belonging to the CD4 T-cell subset. In this form of antigen expression, virus replication and endogenous protein synthesis are not required, but factors such as chloroquine, which alter lysosomal $\mathrm{pH}$ and inhibit lysozyme activity, can abrogate antigen processing.

The second mechanism involves endogenously produced virus proteins and presumably occurs at or near the Golgi complex. The virus antigens are likely degraded proteins resulting from either excessive or defective virus protein synthesis. In Golgi-associated endosomes, virus peptides interact with class I MHC molecules and are also transported to the infected cell membrane where the complexes stimulate CD8 T-cell responses. Virus protein synthesis is required for this form of antigen presentation, and chloroquine treatment has no effect. While both forms of antigen processing may occur simultaneously during normal infec- tions, cells transfected with expression vectors containing virus genes exclusively produce epitopes associated with class I MHC antigens. Presumably, bypassing the lysosomes excludes interactions with class II antigens. Whether persistent infections identified by in situ hybridization studies result in production of virus peptides capable of chronically stimulating virus-specific immunity is not known. However, should this occur, one might hypothesize that only CD8 T-cell responses would arise since such peptides would be endogenously produced and, therefore, should associate with class I MHC antigens.

Two distinct CTL responses follow experimental coxsackievirus infections in mice (59). One, designated virus-specific CTL, closely resembles the response described by the above investigators for exogenously produced virus peptides. Exposure of cardiocytes to either infectious or ultravioletirradiated, noninfectious CVB3 results in virus epitope expression capable of stimulating exclusively CD4 T cells (29). Furthermore, as expected for this subset of effector cells, activity is class II MHC antigen restricted. Virusspecific VCTL distinguish between targets infected with CVB3 and other viruses such as EMC virus, demonstrating the antigen specificity of the response. No CD8 CTL reacting to coxsackievirus-infected cardiocytes have yet been described. One explanation is that the second pathway of antigen processing through Golgi-associated endosomes does not occur in cardiocytes, or possibly in any picornavirus-infected cell. Certainly, the CD8 virus-specific CTL described earlier were noted in influenza virus infections. Since this enveloped virus normally buds from the infected cell, and therefore requires insertion of virus glycoproteins into the plasma membrane, these virus molecules may be more likely to pass through the Golgi than picornavirus proteins which are not glycosylated and are required in the cytoplasm for virion assembly. Differences in cell compartmentalization of virus protein synthesis and utilization may favor one form of antigen processing over another and, therefore, be responsible for different types of virus-specific cellular immunity.

A second CTL that recognizes infected target cells has been described recently (55a). This CTL, unlike the virusspecific CTL, reacts to glycoproteins induced soon after infection but apparently not encoded in the virus genome. Gauntt and his colleagues first described an 80-kilodalton antigen on coxsackievirus-infected cells but not on uninfected cells $(110,111)$. The new antigen, which reacts with the lectin Ulex europeaus agglutinin I, must contain carbohydrate elements. Since picornavirus proteins are not usually glycosylated, these investigators concluded that the new antigen must be of cellular origin and therefore represents a neoantigen (82). Subsequently, a CTL was isolated which reacts to new cellular antigens induced on cardiocytes when cellular metabolism, including RNA and protein syntheses, is inhibited (55a). This CTL (designated metabolic CTL) was first identified when cardiocytes were treated with actinomycin D. Antigenic alterations in the cell membrane correlated identically with decreases in both uridine and leucine incorporation. Not surprisingly, identical antigenic changes were subsequently demonstrated on cardiocytes infected with either the myocarditic CVB3 variant or EMC virus, which both effectively inhibit cellular metabolism. A second and nonpathogenic CVB3 variant does not detectably alter protein synthesis in infected cells and fails to induce antigenic alterations recognizable by the metabolic CTL (55a). The nature of the antigen induced after metabolic alteration is not known but possibly represents a stress-related protein. An 
important point, however, is that the same antigen arises after a variety of drug and virus treatments as long as cellular metabolism is altered. When multiple exposures to such agents are possible, the metabolic CTL may become increasingly important in both eliminating infected cells prior to completion of progeny virion replication and producing cardiac myocytolysis.

\section{AUTOIMMUNITY IN MYOCARDITIS}

A current controversy is centered on determining the major cause of cardiac injury in myocarditis patients. In some patients, cardiac lesions must result primarily from immunological mechanisms since immunosuppressive therapy proves markedly beneficial to these individuals $(32,94)$. However, since many other patients either fail to improve or deteriorate during treatment (53), other mechanisms, including direct virus-mediated injury, may contribute to tissue injury. Myocytolysis resulting from replication and clearance of the infectious agent by either the virus itself or virus-specific immunity should be active only during periods of continued virus presence. Chronic myocarditis in both humans and mice persists for extended periods, after infectious virus can no longer be detected in the heart and when in situ hybridization procedures cannot demonstrate virus genomic material $(12,42)$.

The question arises as to whether the initiating virus infection induces autoimmunity in the host to self-antigens. Several specific immunologic abnormalities have been identified in human myocarditis. Heart-reactive autoantibodies arise in 80 to $100 \%$ of myocarditis patients with a proven or suspected viral etiology. These antibodies are directed against a sizable array of distinct self-antigens including collagen, laminin, and fibronectin of the extracellular matrix (89), myosin $(103,104)$, actin $(89), \mathrm{Ca}^{2+}$ channel proteins (127a), and adenosine diphosphate-adenosine triphosphate carrier molecules usually associated with mitochondrial membranes (127). Other autoantibodies exist which react to as yet unidentified cell surface molecules. Since at least some of these humoral effectors occur in apparently normal individuals and in individuals with ischemic heart injury, their role in causing cardiac damage in myocarditis is unclear.

Perhaps some of the most convincing evidence for a humoral immunopathogenic mechanism in clinical myocarditis comes from work done on antibodies directed to either calcium channel proteins $(127 \mathrm{a})$ or myolemmal antigens (88). In the former studies, antibodies to the calcium channel or sarcolemmal proteins rapidly induced arrhythmias and physiological alterations. These antisarcolemmal antibodies lyse cultured myocytes in complement and antibody-dependent cell-mediated cytotoxicity assays and may therefore contribute to myocardial necrosis and myofiber dropout. Antisarcolemmal antibody titers correlate with disease severity, increasing during acute phases and waning as myocarditis resolves. Evidence for cellular autoimmunity in clinical disease is more difficult to obtain. Abnormal helper and suppressor T-lymphocyte numbers are observed during myocarditis $(3,26,34,122)$, and $\mathrm{T}$ lymphocytes derived from biopsy specimens show significant reactivity to cardiac antigens in culture $(75,88,89)$.

While evidence of autoimmunity in human myocarditis remains only circumstantial, proof of such responses in the murine models is well accepted. Studies by Rose, Beisel, Wolfgram, Herskowitz, and their co-workers show that susceptibility to CVB3-induced myocarditis is under multi- genic control $(51,118 \mathrm{a})$. These genes reside both within and outside of the MHC or $H-2$ region in the mouse and involve the loci controlling $\mathrm{T}$-cell receptor and immunoglobulin responses. Autoantibodies to the heart arise in most strains of mice infected with coxsackievirus and are presumably pathogenic in many. DBA/2 mice inoculated with CVB3 develop a strong antiheart IgG response, and these antibodies can be detected in infected hearts by immunofluorescence (60). Myocardial injury can be completely prevented in this strain by either complement depletion (60) or depletion of L3T4 + (T-helper) cells by monoclonal antibody (78).

Several investigators $(2,103,105,118 \mathrm{a})$ have also found that autoimmune heart antibodies are generated in strains of mice susceptible to chronic myocarditis. The autoantibody correlating most closely with tissue injury is directed against cardiac myosin $(2,103)$. No cross-reactivity of this antibody with specific CVB3 antigens has been observed (104). Immunization of susceptible mice with purified cardiac myosin elicits myocardial pathology within 14 to 21 days. IgG antibodies are present in the heart, and the relative amount of immunoglobin directly correlates to the severity of pathologic changes (118a). Furthermore, various strains of mice differ dramatically in their humoral response to the cardiac myosin isoform and only high responder strains develop myocarditis, further proving that autoimmunity to myosin is important in disease pathogenesis $(103,105)$. It is unclear why myosin should elicit the bulk of an autoimmune response, and this may not be true for all animal strains exhibiting humoral autoimmunity. Possibly, viral injury of some cardiocytes results in increased myosin availability to the immune system similar to the hypothesized mechanisms of myelin basic protein autosensitization in experimental allergic encephalitis $(55,117 a)$.

Cellular autoimmunity also occurs during CVB3 myocarditis. CTL lysing infected and uninfected cardiocytes are detected in peripheral lymphoid tissue within 5 days of virus inoculation, and this activity peaks between weeks 1 and 2 , when pathology is maximum. Lymphocytes positively selected for reactivity to uninfected myocytes demonstrate the existence of autoimmune CTL (59). These effector cells recognize normally expressed antigens on uninfected cardiocytes. Autoimmune CTL belong to the CD8 phenotype, and depletion of this T-cell subset in vivo with monoclonal antibodies abrogates cardiac inflammation in infected mice (29). Furthermore, autoimmune CTL effectively transfer myocarditis when adoptively injected into uninfected syngeneic animals, confirming both their autoimmune nature and their pathogenic potential (61).

One of the interesting observations in the murine model is that, while genetically dissimilar mice may show equal susceptibility to CVB3-induced myocarditis and while the lesions appear similar histologically, the pathogenic mechanisms in tissue injury vary dramatically. Thus, one strain of animal develops exclusively CD4 and IgG heart-reactive autoantibody-dependent myocarditis, yet in a second strain, CD8 cells are all-important and humoral autoantibodies, though present, play no demonstrable role in myocardial injury (78). Other strains show either a mixture of CD4- and CD8-dependent immunopathogenic mechanisms or develop T-cell-independent inflammatory heart disease (78). The important lesson from the animal model may be that myocarditis is a complex collection of diseases presenting with many similar clinical and histological characteristics but differing markedly from each other in fundamental etiology and pathogenesis. Furthermore, which disease mechanism operates in an individual may prove highly important in 
successful management and therapy, since animal studies indicate that CD8 autoimmune $\mathrm{T}$ cells may belong to a steroid-resistant lymphocyte population which cannot be inactivated with standard forms of immunosuppressive therapy (prednisone and cyclosporin A) (30).

How virus infection ultimately leads to autoimmunity is an important unresolved issue. Several mechanisms have been proposed. First, autoimmunity may arise through antigenic mimicry between the virus and cell. Such cross-reactivity has been noted with numerous infectious agents, including streptococcal antigens and cardiac tissues in rheumatic heart disease (20) and $T$. cruzi membrane proteins and myocytes in Chagas' disease $(119,137)$. Notkins et al. have reported mimicry in coxsackieviral myocarditis, using a single monoclonal antibody which both neutralizes CVB4 and reacts to murine myocardium (J. Sacgusa, B. S. Prabhakar, K. Essani, P. R. McClintock, Y. Fukuda, V. J. Ferrano, and A. L. Notkins, Letter, J. Infect. Dis. 153:372, 1986). Whether this form of autoimmunity plays a major role in pathogenesis is not known, but it certainly will be investigated in the future. A second mechanism has been suggested in many autoimmune diseases. Susceptible animals and humans may have specific defects in their suppressor cell repertoire which allow inadvertent responses to self-antigens (65). Several groups report defective suppressor cell activity in myocarditis patients not found in healthy individuals or persons with other forms of heart disease $(26,90)$. Also, suppressor cells may play a role in determining susceptibility or resistance to CVB3-induced murine myocarditis. Under certain conditions, virus infection of the myocardium fails to elicit an inflammatory response.

Although most forms of autoimmune disease are predominant in females, in the murine myocarditis model male mice are highly susceptible while females are largely resistant (58). This resistance can be eliminated, however, during pregnancy and in the postpartum period when female animals develop as much or more severe myocarditis than males (84). Interestingly, this pattern is also present in humans. As of 1980 , approximately two-thirds of myocarditis cases were reported in men. Of the remaining cases occurring in women, the majority arose during the third trimester of pregnancy and in the postpartum period (147). Thus, epidemiologically, the murine disease resembles the human disease with surprising accuracy. Animal studies indicate that female resistance is complex, but depends primarily on the protective effects of estrogens, while susceptibility in males and pregnant females results from elevated androgen (testosterone and progesterone) levels. The latter hormones enhance picornavirus receptor expression on cardiocytes nearly fourfold. Virus localizes and replicates more rapidly in the hearts of androgen-treated animals (85) and stimulates autoimmune cellular and humoral responses which are noticeably absent in estrogen-treated mice $(83,84)$. Lack of autoimmune reactivity in the latter case depends exclusively on the preferential induction of antigen-specific suppressor cells (65). Why estrogens promote suppressor cell generation while androgens support autoimmunity is not known. However, current evidence implicates the virus receptor as an important element in autoimmune responses $(25,70,93)$. Androgen-treated cardiocytes show concurrent augmentation in both receptor expression and antigenicity for autoimmune CTL, proving the initial suggestion that these autoimmune mediators may recognize the receptor as their target antigen (85). Subsequent work with monoclonal antibodies to the CVB3 receptor on murine heart cells confirms this supposition (57a).
Thus, lowering receptor concentration can influence stimulation of autoimmunity by both providing less antigen for autoimmune effectors and stimulating suppressor cells through low-dose tolerance.

Other hypotheses for autoimmunity after virus infection must also be considered. Two common experimental mechanisms are used for inducing autoimmunity to a variety of tissue antigens. The first involves inoculating animals with the appropriate materials in complete Freund adjuvant. A well-known example of this mechanism is demonstrated by experimental allergic encephalitis in which a demyelinating neurological disease is initiated by injecting mice with myelin basic protein and adjuvant $(9,142)$. A second similar mechanism requires either haptenization of the self-molecule with a highly antigenic moiety or inoculation of the functional molecule from a different species which bears marked similarities to the self-antigen, yet also possesses important antigenic "foreignness." For example, hemolytic anemia has been reported after injection of mice with haptenized syngeneic erythrocytes (102). While destruction of the haptenated cells would be expected, because of the added antigenic moiety, normal erythrocytes were also destroyed. Weigle initiated autoimmune thyroiditis in mice by inoculating these animals with bovine thyroglobulin (142). Finally, and perhaps of most relevance, several studies have demonstrated induction of autoimmune-like diseases after virus infection and specifically when animals are given virus covalently adsorbed to cell membranes, presumably attached to the specific virus receptor (25). Under these conditions, the virus presumably acts as a "hapten" for the self-molecule. How alterations in self-molecules result in autoimmunization is only partially understood. Although tolerance exists at the level of both $\mathrm{T}$ and $\mathrm{B}$ lymphocytes, persistent nonreactivity usually depends on deletion or inactivation of self-recognizing T-cell clones. Thus, autoreactive $B$ cells may be present commonly, yet fail to give rise to detectable autoimmunity in the absence of appropriate $\mathrm{T}$ helper cells. However, when an autoantigen is modified with an "antigenic" component for which appropriate T-helper cells exist, these $\mathrm{T}$ cells may inadvertently supply the required lymphokines and cellular interactions necessary to stimulate the autoimmune B cells (142). Similarly, some self-molecules may be antigenic to both $\mathrm{T}$ - and B-cell clones, but are never appropriately presented to the immune system in conjunction with the proper MHC antigens to stimulate autoimmune responses. The function of the adjuvant or antigenic hapten or both may be primarily to either (i) facilitate antigen presentation of the self-molecules by concentrating inflammatory cells in the vicinity of the selfmolecules, thus enhancing phagocytosis of both stimulating and self-antigens; or (ii) elicit gamma interferon release from $T$ cells stimulated to the antigenic moiety which will induce MHC expression on tissues. In the latter case, the inappropriate expression of the MHC antigens may cause the tissues themselves to take on many of the required characteristics of antigen-presenting cells and stimulate autoimmunity.

Finally, autoimmunity may result as a consequence of anti-idiotypic immunity $(13,112)$. Because of the large array of potential antigenic epitopes each individual can recognize, very few $T$ and $B$ cells committed to a particular epitope exist within the body under normal circumstances. When antigenic stimulation occurs, a rapid clonal expansion of the involved cells takes place and antibodies are produced with specific variable regions or idiotypes for binding to the inducing antigen. The change from a paucity to an abundance of the particular idiotype frequently results in induc- 
tion of an anti-idiotypic response in which the antigenbinding site of the antibody itself appears foreign to the immune system. Since the anti-idiotype is complementary to the three-dimensional structure of the original antigenbinding region, the anti-idiotype variable region often resembles the original antigen (28). Thus, virus infection will usually initiate a virus-neutralizing antibody response which binds to appropriate epitopes on the virus and prevents interaction of the infectious agent with the receptor on the cell surface $(70,93)$. An anti-idiotypic response arising to the virus-neutralizing antibody may result in an internal image quite similar to the relevant virus components involved in receptor attachment. In this case, the anti-idiotype may react directly with the receptor much as the virus would, giving the phenotypic appearance of an autoimmune response. Evidence from both experimental and clinical Chagasic myocarditis implicates this mechanism of autoimmunity in tissue injury (140a). The pathologic immune response not only reacts to the $T$. cruzi antibody, which prevents the organism from attaching to the myocytes (idiotypic antibody), but also recognizes the trypanosome attachment site on the cardiac tissue. How common this form of autoimmunity may prove to be in other types of myocarditis is unclear and, as yet, unknown.

\section{CONCLUSIONS}

The above discussion presents various ways in which cardiac injury may follow virus infections. Certainly, any or all of these may occur simultaneously in a single individual or, alternatively, distinct mechanisms may predominate in each case. Other mechanisms may ultimately be found which are not identified here. This review is designed primarily to provide the reader with an appreciation for the complexity of human and experimental viral myocarditis and to discuss the present knowledge available regarding its pathogenesis.

Since much of the information outlined here depends heavily on animal models, one might question whether the experimental data truly reflect the human experience. This vital point cannot be addressed at this time because the data are incomplete. There definitely are areas of striking similarity between the human disease and murine myocarditis, both in the appearance of histologic lesions and in the demonstration of various cellular and humoral autoimmune responses, yet differences also exist. How important these differences prove to be and whether the animal models facilitate development of improved methods for diagnosis and treatment of the human disease may depend largely on the ability of the experimentalist and the clinician to work together in finding a solution to this problem.

\section{ACKNOWLEDGMENTS}

This work was supported by Public Health Service grants HL 28833 and HL 33256 from the National Heart, Lung, and Blood Institute, by American Heart Association grant-in-aid 87-0834, and by a grant-in-aid to Kevin Leslie from the American Heart Association-Vermont Affiliate.

We gratefully acknowledge the expert secretarial assistance of Laurie Sabens, who helped organize and prepare this manuscript.

\section{LITERATURE CITED}

1. Abelmann, W. H. 1984. Classification and natural history of primary myocardial disease. Prog. Cardiovasc. Dis. 27:73-94.

2. Alvarez, F. L., N. Neu, N. R. Rose, S. W. Craig, and K. W. Beisel. 1987. Heart-specific autoantibodies induced by cox- sackievirus B3: identification of heart autoantigens. Clin. Immunol. Immunopathol. 43:129-139.

3. Anderson, J. L., J. F. Carlquist, and R. Hibashikub. 1985. Quantitation of lymphocyte subsets by immunofluorescence flow cytometry in idiopathic dilated cardiomyopathy. Am. J. Cardiol. 55:1550-1554.

4. Aretz, H. T., M. E. Billingham, and W. D. Edwards. 1987. Myocarditis-a histopathologic definition and classification. Am. J. Cardiovasc. Pathol. 1:3-14.

5. Ayuthya, P. S. N., V. J. Jayavasu, and B. Pongpenich. 1974. Coxsackie group $\mathrm{B}$ virus and primary myocardial disease in infants and children. Am. Heart J. 88:311-314.

6. Baltimore, D. 1969. The replication of picornaviruses, p. 101176. In H. B. Levy (ed.), Biochemistry of viruses. Marcel Dekker, Inc., New York.

7. Baltimore, D., R. M. Franklin, and J. Callender. 1963. Mengovirus-induced inhibition of host ribonucleic acid and protein synthesis. Biochim. Biophys. Acta 76:425-436.

8. Bengtsson, E., and B. Lamberger. 1966. Five year follow-up study of cases suggestive of acute myocarditis. Am. Heart J. 72:751-763.

9. Ben-Nun, A., and I. R. Cohen. 1982. Experimental autoimmune encephalomyelitis (EAE) mediated by T cell lines. Process of selection of lines and characterization of the cells. J. Immunol. 129:303-308.

10. Billingham, M. E., and J. W. Mason. 1984. Endomyocardial biopsy diagnosis of myocarditis, p. 201-210. In H.-D. Bolte (ed.), Viral heart disease. Springer-Verlag, Berlin.

11. Billingham, M. E., and H. D. Tazelaar. 1986. The morphological progression of viral myocarditis. Postgrad. Med. J. 62: 581-584.

12. Bowles, N. E., P. J. Richardson, E. G. J. Olsen, and L. C. Archard. 1986. Detection of Coxsackie B virus-specific RNA sequences in myocardial biopsy samples from patients with myocarditis and dilated cardiomyopathy. Lancet $\mathbf{i}: 1120-1122$.

13. Bruck, C., M. S. Co., M. Slaoui, G. N. Gaulton, T. Smith, B. N. Fields, J. I. Mullins, and M. I. Greene. 1986. Nucleic acid sequence of an internal image-bearing monoclonal anti-idiotype and its comparison to the sequence of the external antigen. Proc. Natl. Acad. Sci. USA 83:6578-6582.

14. Burch, G. E., S. C. Sun, H. L. Colcolough, R. S. Sohal, and N. P. De Pasquale. 1967. Coxsackie B viral myocarditis and valvulitis identified in routine autopsy speciemsn by immunofluorescent techniques. Am. Heart J. 74:13-23.

15. Burns, W. H., L. C. Billups, and A. L. Notkins. 1975. Thymus dependence of viral antigens. Nature (London) 256:654-656.

16. Craighead, J. E. 1979. Cytopathology and diagnostic virology, p. 143-158. In D. A. Lennette, S. Specter, and K. D. Thompson (ed.), Diagnosis of viral infections: the role of the clinical laboratory. University Park Press, Baltimore.

17. Crawford, N., A. Fire, M. Samuels, P. A. Sharp, and D. Baltimore. 1981. Inhibition of transcription factor activity by poliovirus. Cell 27:555-561.

18. Crowell, R. L. 1976. Comparative generic characteristics of picornavirus-receptor interactions, p. 179-202. In R. Beers and E. Bassett (ed.), Cell membrane receptors for viruses, antigens, and antibodies, polypeptide hormones, and small molecules. Raven Press, New York.

19. Crowell, R. L., A. K. Field, W. A. Schlief, W. L. Loney, R. J. Colonno, J. E. Mapoles, and E. A. Emini. 1986. Monoclonal antibody that inhibits infection of HeLa and rhabdomyosarcoma cells by selected enteroviruses through receptor blockade. J. Virol. 57:438-445.

20. Cunningham, M. W., N. K. Hall, K. K. Kusher, and A. M. Spanier. 1986. A study of anti-group A streptococcal monoclonal antibodies cross-reactive with myosin. J. Immunol. 136: 293-298.

21. Dalldorf, G., and G. M. Sickles. 1948. An unidentified, filtrable agent isolated from the feces of children with paralysis. Science 108:61-62.

22. DeSena, J., and B. Mandel. 1977. Studies on the in vitro uncoating of poliovirus. II. Characterization of the membrane modified particle. Virology 78:554-566. 
23. Doane, F. W. 1974. Identification of viruses by immunoelectron microscopy, p. 237-255. In E. Kurstak and A. Morissett (ed.), Viral immunodiagnosis. Academic Press, Inc., New York.

24. Doherty, P. C., R. V. Blanden, and R. M. Zinkernagel. 1976. Specificity of virus-immune effector $\mathrm{T}$ cells for $\mathrm{H}-2 \mathrm{~K}$ or $\mathrm{H}-2 \mathrm{D}$ compatible interactions: implications for $\mathrm{H}$-antigen diversity. Transplant. Rev. 28:89-124.

25. Eaton, M: D. 1980 . Autoimmunity induced by syngeneic splenocyte membranes carrying irreversibly absorbed paramyxovirus. Infect. Immun. 27:855-861.

26. Eckstein, R., W. Mempel, and H.-D. Bolte. 1982. Reduced suppressor cell activity in congestive cardiomyopathy and in myocarditis. Circulation 65:1224-1229.

27. Elk Holy, A., J. Rotta, L. W. Wannamaker, T. Strasser, B. Bytchenko, W. Ferreire, L. Houang, and E. Lissberg. 1978. Recent advances in rheumatic fever control and future prospects: a World Health Organization memorandum. Bull. W.H.O. 56:887-912.

28. Erlanger, B. F., W. L. Cleveland, N. H. Wassermann, H. H. Ku, B. L. Hill, R. Sarangarajan, R. Rajagopulan, E. Cayanis, S. Edelman, and A. S. Penn. 1986. Auto-anti-idiotypy: a basis for autoimmunity and a strategy for anti-receptor antibodies. Immunol. Rev. 94:23-38.

29. Estrin, M., and S. A. Huber. 1987. Coxsackievirus B3-induced myocarditis: autoimmunity is L3T4+ T helper cell and IL-2 independent in Balb/c mice. Am. J. Pathol. 127:335-341.

30. Estrin, M., C. Smith, and S. Huber. 1986. Coxsackievirus B-3 myocarditis $\mathrm{T}$ cell autoimmunity to heart antigens is resistant to Cyclosporin A treatment. Am. J. Pathol. 125:18-25.

31. Etchison, D., J. Hansen, E. Ehrenfeld, I. Edery, N. Sonenburg, S. Milburn, and J. W. B. Hershey. 1984. Demonstration in vitro that eukaryotic initiation factor 3 is active but that 2 capbinding protein complex is inactive in poliovirus-infected HeLa cells. J. Virol. 51:832-837.

32. Fenoglio, J. J., Jr., P. C. Ursell, C. F. Kellogg, M. Phil, R. E. Drusin, and M. B. Weiss. 1983. Diagnosis and classification of myocarditis by endomyocardial biopsy. N. Engl. J. Med. 308:12-18.

33. Finberg, R., and B. Benacerraf. 1981. Induction, control, and consequences of virus specific cytolytic $\mathrm{T}$ cells. Immunol. Rev. 58:157-180.

34. Fowles, R. E., C. P. Bieber, and E. B. Stinson. 1979. Defective in vitro suppressor cell function in idiopathic congestive cardiomyopathy. Circulation 59:483-491.

35. Fowles, R. E., and J. W. Mason. 1984: Role of cardiac biopsy in the diagnosis and management of cardiac diseases. Prog. Cardiovasc. Dis. 27:153-172.

36. Gardiner, A. J. S., and D. Short. 1973. Four phases of acute myopericarditis. Br. Heart J. 35:433-442.

37. Gauntt, C. J., P. T. Gomez, P. S. Duffey, S. A. Grant, D. W. Trent, S. M. Witherspoon, and R. E. Paque. 1984. Characterization and myocarditic capabilities of coxsackievirus B3 variants in selected mouse strains. J. Virol. 52:598-605.

38. Gauntt, C. J., M. D. Trousdale, D. R. L. LaBadie, R. E. Paque, and T. Nealon. 1979. Properties of coxsackievirus B3 variants which are amyocarditic or myocarditic for mice. J. Med. Virol. 3:207-220.

39. Gear, J., V. Measroch, and F. R. Prinsloo. 1956. The medical and public health importance of the coxsackie viruses. S. Afr. Med. J. 30:806-810.

40. Germain, R. N. 1986. Immunology: the ins and outs of antigen processing and presentation [news]. Nature (London) 322: 687-689.

41. Godeny, E. K., and C. J. Gauntt. 1986. Involvement of natural killer cells in coxsackievirus B3 induced murine myocarditis. J. Immunol. 137:1695-1702.

42. Godeny, E. K., and C. J. Gauntt. 1987. In situ immune autoradiographic infection of cells in heart tissues of mice with coxsackievirus B3-induced myocarditis. Am. J. Pathol. 129: 267-276.

43. Godeny, E. M., and C. J. Gauntt. 1987. Murine natural killer cells limit coxsackievirus B3 replication. J. Immunol. 139: 913-918.
44. Godman, G. C., H. Bunting, and J. L. Melnick. 1952. The histopathology of coxsackievirus infection in mice. I. Morphologic observations with four different viral types. Am. J. Pathol. 28:223-257.

45. Goller, T. 1986. Experimental reovirus myocarditis in newborn mice. Electron microscopic observations. Virchows Arch. B 50:373-386.

46. Grodums, E. I., and G. Dempster. 1959. The age factor in experimental coxsackie B3 infection. Can. J. Microbiol. 5: 595-603.

47. Grodums, E. I., and G. Dempster. 1959. Myocarditis in experimental coxsackie B3 infection. Can. J. Microbiol. 5:605-615.

48. Grodums, E. I., and G. Dempster. 1962. The pathogenesis of coxsackie group B viruses in experimental infection. Can. J. Microbiol. 8:105-113.

49. Hashimoto, I., and T. Tomatsu. 1978. Myocardial changes after infection with coxsackievirus $\mathrm{B} 3$ in nude mice. $\mathrm{Br}$. J. Exp. Pathol. 59:13-20.

50. Helin, M., J. Savola, and K. Lapinleimu. 1968. Cardiac manifestations during a coxsackie B5 epidemic. Br. Med. J. 3: 97-99.

51. Herskowitz, A., L. J. Wolfgram, N. R. Rose, and K. W. Beisel. 1987. Coxsackievirus B3 murine myocarditis: a pathologic spectrum of myocarditis in genetically defined inbred strains. J. Am. Coll. Cardiol. 9:1311-1319.

52. Hirschman, S. Z., and G. S. Hammer. 1974. Coxsackievirus myopericarditis: a microbiological and clinical review. Am. J. Cardiol. 34:224-232.

53. Hosenpud, J. D., J. H. McAnulty, and N. R. Niles. 1985. Lack of objective improvement in ventricular systolic function in patients with myocarditis treated with azathioprine and prednisone. J. Am. Coll. Cardiol. 6:797-801.

54. Hsuing, G. D., and J. L. Melnick. 1957. Morphologic characteristics of plaques produced on monkey kidney monolayer cultures by enteric viruses (poliomyelitus, coxsackie and echo groups). J. Immunol. 78:128-136.

55. Huang, S. K., and S. Sriram. 1988. Clonal diversity of myelin basic protein-specific $\mathrm{T}$ lymphocytes. Immunogenetics 27: 370-375.

55a.Huber, S. A., N. Heintz, and R. Tracy. 1988. Coxsackievirus B-3 induced myocarditis: virus and actinomycin D treatment of myocytes induces novel antigens recognized by cytolytic $T$ lymphocytes. J. Immunol. 141:3214-3219.

56. Huber, S. A., and L. P. Job. 1983. Cellular immune mechanisms in coxsackievirus group B type 3 induced myocarditis in Balb/c mice. Adv. Exp. Med. Biol. 161:491-508.

57. Huber, S. A., and L. P. Job. 1983. Differences in cytolytic T-cell response of BALB/c mice infected with myocarditic and nonmyocarditic strains of coxsackievirus group B, type 3 . Infect. Immun. 39:1419-1427.

57a.Huber, S. A., K. Simpson, A. Weller, and M. Herzum. 1988. Immunopathogenic mechanisms in experimental myocarditis: evidence for autoimmunity to the virus receptor and antigenic mimicry between the virus and the cardiocyte. Pathol. Immunopathol. Res. 7:279-291.

58. Huber, S. A., L. P. Job, and K. R. Auld. 1982. Influence of sex hormones on Coxsackie B3 virus infection in Balb/c mice. Cell. Immunol. 67:173-189.

59. Huber, S. A., and P. A. Lodge. 1984. Coxsackievirus B-3 myocarditis in Balb/c mice. Evidence for autoimmunity to myocyte antigens. Am. J. Pathol. 116:21-29.

60. Huber, S. A., and P. A. Lodge. 1986. coxsackievirus B3 myocarditis: identification of different pathogenic mechanisms in DBA/2 and Balb/c mice. Am. J. Pathol. 122:284-291.

61. Huber, S. A., P. A. Lodge, M. Herzum, M. Estrin, and J. Olzsewski. 1987. The role of T lymphocytes in the pathogenesis of coxsackievirus B-3 myocarditis, p. 9-22. In C. Kawai and W. Abelmann (ed.), Pathogenesis of myocarditis and cardiomyopathy. University of Tokyo Press, Tokyo.

62. Huber, S. A., P. A. Lodge, and L, P. Job. 1984. The role of virus and immune mediated cardiocyte injury in coxsackievirus B3-induced myocarditis, p. 64-73. In H.-D. Bolte (ed.), Viral heart disease. Springer-Verlag, Berlin. 
63. Jen, G., B. M. Detjen, and R. E. Thach. 1980. Shutoff of HeLa cell protein synthesis by encephalomyocarditis virus and poliovirus: a comparative study. J. Virol. 35:150-156.

64. Jen, G., and R. E. Thach. 1982. Inhibition of host translation in encephalomyocarditis virus-infected L cells: a novel mechanism. J. Virol. 43:250-261.

65. Job, L. P., D. C. Lyden, and S. A. Huber. 1986. Demonstration of suppressor cells in Coxsackievirus Group B Type 3 infected female Balb/c mice which prevent myocarditis. Cell. Immunol. 98:104-113

66. Jungebult, C. W., and D. E. Edwards. 1951. Isolation of poliomyelitis virus from the heart in fatal cases. Am. J. Clin. Pathol. 21:601-623.

67. Kandolf, R., D. Ameis, P. Kirschner, A. Canue, and P. H. Hofschneider. 1987. In situ detection of enteroviral genomes in myocardial cells by nucleic acid hybridization: an approach to the diagnosis of viral heart disease. Proc. Natl. Acad. Sci. USA 84:6272-6276.

68. Kandolf, R., A. Canu, and P. H. Hofschneider. 1985. Coxsackie B3 virus can replicate in cultured human fetal heart cells and is inhibited by interferon. J. Mol. Cell. Cardiol. 17:167-181.

69. Kauffman, R. S., and B. N. Fields. 1985. Pathogenesis of viral infections, p. 153-167. In B. Fields (ed.), Virology. Raven Press, New York.

70. Kauffman, R. S., J. H. Noseworthy, J. T. Nepom, R. Finberg, B. N. Fields, and M. I. Green. 1983. Cell receptors for the mammalian reovirus. II. Monoclonal anti-idiotypic antibody blocks viral binding to cells. J. Immunol. 131:2539-2541.

71. Kilbourne, E. D., and F. L. Horsfall, Jr. 1951. Lethal infection with coxsackie virus of adult mice given cortisone. Proc. Soc. Exp. Biol. Med. 77:135-138.

72. Kilbourne, E. D., C. B. Wilson, and D. Perrier. 1956. The induction of gross myocardial lesions by coxsackie (pleurodynia) virus and cortisone. J. Clin. Invest. 35:362-370.

73. Kitaura, Y., and H. Morita. 1979. Secondary myocardial disease. Virus myocarditis and cardiomyopathy. Jpn. Circ. J. 43:1017-1031.

74. Kline, I. K., and O. Saphir. 1960. Chronic pernicious myocarditis. Total of 29 cases documented progressive myocardital failure and death within months to years. Am. Heart J. 59:681-697.

75. Kurnick, J. T., C. Leary, I. F. Palacios, and J. T. Fallon. 1987. Culture and characterization of lymphocytic infiltrates from endomyocardial biopsies of patients with idiopathic myocarditis. Eur. Heart J. 8(Suppl.):135-139.

76. Lerner, A. M., and F. M. Wilson. 1973. Virus myocardiopathy. Prog. Med. Virol. 15:63-91.

77. Lerner, A. M., F. M. Wilson, and M. P. Reyes. 1975. Enteroviruses and the heart (with special emphasis on the probable role of Coxsackie viruses, Group B, Types 1-5). II. Observations in humans. Mod. Concepts Cardiovasc. Dis. 44:1115.

78. Lodge, P. A., M. Herzum, J. Olszewski, and S. A. Huber. 1987. Coxsackievirus B-3 myocarditis: acute and chronic forms of the disease caused by different immunopathogenic mechanisms. Am. J. Pathol. 128:455-463.

79. Lou, T. Y., H. A. Wenner, and P. S. Kamitsuka. 1961. Experimental infections with Coxsackie viruses. II. Myocarditis in cynomolgus monkeys infected with B4 virus. Arch. Ges. Virusforsch. 10:451-464.

80. Lukacher, A. E., L. A. Morrison, V. L. Braciale, B. Malissen, and T. J. Braciale. 1985. Expression of specific cytolytic activity by $\mathrm{H}-2 \mathrm{I}$ region-restricted influenza virus-specific $\mathrm{T}$ lymphocyte clones. J. Exp. Med. 162:171-187.

81. Luo, M., G. Vriend, and G. Kamer. 1987. The atomic structure of Mengo virus at 3.0 $\AA$ resolution. Science 235:182-191.

82. Lutton, C. W., and C. J. Gauntt. 1986. Coxsackievirus B3 infection alters plasma membrane of neonatal skin fibroblasts. J. Virol. 60:294-296.

83. Lyden, D., J. Olszewski, and S. Huber. 1987. Variation in susceptibility of Balb/c mice to coxsackievirus group B type 3-induced myocarditis with age. Cell. Immunol. 105:332339.
84. Lyden, D. C., and S. A. Huber. 1984. Aggravation of coxsackievirus group B type 3-induced myocarditis and increase in cellular immunity to myocyte antigens in pregnant $\mathrm{Balb} / \mathrm{c}$ mice and animals treated with progesterone. Cell. Immunol. 87: 462-472.

85. Lyden, D. C., J. Olszewski, M. Feran, L. P. Job, and S. A. Huber. 1987. coxsackievirus B-3 induced myocarditis. Effect of sex steroids on viremia and infectivity of cardiocytes. Am. J. Pathol. 126:432-438.

86. Madshus, I. H., S. Olsnes, and K. Sandvig. 1981. Different pH requirements for entry of the two picornaviruses, human rhinovirus 2 and murine encephalomyocarditis virus. Virology 139:346-357.

87. Madshus, I., K. Sandvig, S. Olsnes, and B. van Deurs. 1987. Effect of reduced endocytosis induced by hypotonic shock and potassium depletion on the infection of HEp-2 cells by picornaviruses. J. Cell. Physiol. 131:14-22.

88. Maisch, B. 1986. Immunologic regulator and effector functions in perimyocarditis, postmyocarditic heart muscle disease, and dilated cardiomyopathy. Basic Res. Cardiol. 1(Suppl.):217242.

89. Maisch, B., P. Deeg, G. Liebau, and K. Kochsiek. 1983. Diagnostic relevance of humoral and cytotoxic immune reactions in primary and secondary dilated cardiomyopathy. Am. J. Cardiol. 52:1072-1078.

90. Maisch, B., H. Hauck, U. Koniger, S. Endter, D. Klapf, U. Schmier, I. Auer, and K. Kochsiek. 1987. T suppressor cell activity in (peri)myocarditis and infective endocarditis. Eur. Heart J. 8:147-153.

91. Marboe, C. C., and J. J. Fenoglio, Jr. 1988. Biology diagnosis of myocarditis. Cardiovasc. Clin. 18:137-154.

92. Marboe, C. C., O. M. Knowles, M. B. Weiss, P. C. Ursell, and J. J. Fenoglio, Jr. 1984. Characterization of the inflammatory infiltrate in human myocarditis-an endomyocardial biopsy study, p. 74-86. In H.-D. Bolte (ed.), Viral heart disease. Springer-Verlag, Berlin.

93. Marriott, S. J., D. J. Roeder, and R. A. Consigli. 1987. Anti-idiotypic antibodies to a polyomavirus monoclonal antibody recognize cell surface components of mouse kidney cells and prevent polyomavirus infection. J. Virol. 61:2747-2753.

94. Mason, J. W., M. E. Billingham, and D. R. Ricci. 1980. Treatment of acute inflammatory myocarditis assisted by endocardial biopsy. Am. J. Cardiol. 45:1037-1044.

95. Meany, B. T., P. J. Quigley, E. G. J. Olsen, P. J. Richardson, and D. E. Jewitt. 1987. Recent experience of endomyocardial biopsy in the diagnosis of myocarditis. Eur. Heart J. 8:17-18.

96. Medearis, D. N., Jr. 1957. Cytomegalic inclusions disease: an analysis of the clinical features based on the literature and 6 additional cases. Pediatrics 19:467-480.

97. Melnick, J. 1985. Enteroviruses: polioviruses, coxsackieviruses, echoviruses, and newer enteroviruses, p. 739-794. In B. Fields (ed.), Virology. Raven Press, New York.

98. Meunier, P. C., B. J. Cooper, M. J. Appel, and D. O. Slauson. 1984. Experimental viral myocarditis: parvoviral infection of neonatal pups. Vet. Pathol. 21:509-515.

99. Miklozek, C. L., E. M. Kingsley, C. S. Crumpaker, J. F. Modlin, H. D. Royal, P. C. Come, R. Mark, and W. H. Abelmann. 1986. Serial cardiac function tests in myocarditis. Postgrad. Med. J. 62:577-579.

100. Monif, G. R. G., C. W. Lee, and G. D. Hsiung. 1976. Isolated myocarditis with recovery of ECHO Type 9 virus from the myocardium. N. Engl. J. Med. 277:1353-1355.

101. Morrison, L. A., A. E. Lukacher, V. L. Braciale, D. P. Fan, and T. J. Braciale. 1986. Differences in antigen presentation to MHC class I- and class II-restricted influenza virus-specific cytolytic T lymphocyte clones. J. Exp. Med. 163:903-921.

102. Negoro, S., T. Takashima, H. Fujiwara, and I. Tsuyriguchi. 1979. Regulatory mechanism of autoantibody production in mice to bromelin-treated isologous red blood cells. Immunology 36:257-264.

103. Neu, N., K. W. Beisel, M. D. Traystman, N. R. Rose, and S. W. Craig. 1987. Autoantibodies specific for the cardiac myosin isoform are found in mice susceptible to coxsackievirus B3 
induced myocarditis. J. Immunol. 138:2488-2492.

104. Neu, N., S. W. Craig, N. R. Rose, F. Alvarez, and K. W. Beisel. 1987. Coxsackievirus induced myocarditis in mice: cardiac myosin autoantibodies do not cross-react with the virus. Clin. Exp. Immunol. 69:566-574.

105. Neu, N., N. R. Rose, K. W. Beisel, A. Herskowitz, G. GurriGlass, and S. W. Craig. 1987. Cardiac myosin induces myocarditis in genetically predisposed mice. J. Immunol. 139: 3630-3636.

106. O'Connell, J. B. 1983. Evidence linking viral myocarditis to dilated cardiomyopathy in humans, p. 96 . In J. A. Robinson and J. B. O'Connell (ed.), Myocarditis: precursor of cardiomyopathy. Collamore Press, Lexington, Mass.

107. O'Connell, J. B. 1987. The role of myocarditis in end-stage dilated cardiomyopathy. Tex. Heart J. 14:268-275.

108. O'Connell, J. B., and R. E. Henkin. 1985. Myocardial gallium67 imaging in dilated cardiomyopathy. Postgrad. Med. J. 61:1132-1135.

109. Olsen, E. G. J. 1984. Histomorphological relations between myocarditis and dilated cardiomyopathy, p. 5-12. In H.-D. Bolte (ed.), Viral heart disease. Springer-Verlag, Berlin.

110. Paque, R. E., C. J. Gauntt, T. J. Nealon, and M. D. Trousdale. 1978. Assessment of cell-mediated hypersensitivity against Coxsackievirus B3 viral-induced myocarditis utilizing hypertonic salt extracts of cardiac tissue. J. Immunol. 120:1672-1678.

111. Paque, R. E., D. C. Straus, T. J. Nealon, and C. J. Gauntt. 1979. Fractionation and immunologic assessment of $\mathrm{KCl}-\mathrm{ex}$ tracted cardiac antigens in coxsackievirus B3 virus-induced myocarditis. J. Immunol. 123:358-364.

112. Plotz, P. H. 1983. Autoantibodies are anti-idiotype antibodies to antiviral antibodies. Lancet ii:824-826.

113. Prabhaker, B. S., J. Srinivasappa, and V. Ray. 1987. Selection of coxsackievirus B4 variants with monoclonal antibodies results in attenuation. J. Gen. Virol. 68:865-869.

114. Rabin, E. R., S. A. Hassan, A. B. Jensen, and J. L. Melnick. 1964. Coxsackievirus B3 myocarditis in mice: an electron microscope, immunofluorescent and virus-assay study. Am. J. Pathol. 44:775-797.

115. Raeckert, R. 1985. Picornaviruses and their replication, $p$. 705-738. In B. Fields (ed.), Virology. Raven Press, New York.

116. Rager-Zisman, B., and A. C. Allison. 1973. Effects of immunosuppression on Coxsackievirus B-3 infection in mice and passive protection by circulating antibody. Can. J. Microbiol. 5:605-612.

117. Reyes, M. P., and A. M. Lerner. 1985. Coxsackievirus myocarditis with special reference to acute and chronic effects. Prog. Cardiovasc. Dis. 27:373-394.

117a.Rodriguez, M., and S. Sriram. 1988. Successful therapy of Theiler's virus-induced demyelination (DNA strain) with monoclonal anti-Lyt 2.2 antibody. J. Immunol. 140:2950-2955.

118. Roesing, T. G., P. A. Toselli, and R. L. Crowell. 1975. Elution and uncoating of coxsackievirus B3 by isolated HeLa cell plasma membranes. J. Virol. 15:654-667.

118a.Rose, N. R., D. A. Neumann, and A. Herskowitz. 1988. Genetics of susceptibility to viral myocarditis in mice. Pathol. Immunopathol. Res. 7:266-278.

119. Sadigursky, M., A. M. Acosta, and C. A. Santos-Buch. 1982. Muscle sarcoplasmic reticulum antigen shared by a Trypanosoma cruzi clone. Am. J. Trop. Med. Hyg. 31:934-945.

120. Sainani, G. J., E. Krompotic, and S. J. Slodki. 1968. Adult heart disease due to the Coxsackievirus B infection. Medicine (Baltimore) 47:133-147.

121. Sakakibara, S., and S. Konno. 1962. Endomyocardial biopsy. Jpn. Heart J. 3:537-543.

122. Sanderson, J. E., D. Koech, D. Iha, and H. P. Ojiambo. 1985. T-lymphocyte subsets in idiopathic dilated cardiomyopathy. Am. J. Cardiol. 55:755-758.

123. Saphir, O. 1941. Myocarditis: a general review, with an analysis of two-hundred forty cases. Arch. Pathol. 32:1000-1051; 33:88-137.

124. Saphir, O., G. D. Amromin, and H. Yokoo. 1956. Myocarditis in viral (epidemic) hepatitis. Am. J. Med. Sci. 231:168-176.
125. Schmidt, N. J., E. H. Lennette, and J. Dennis. 1968. Characterization of antibodies produced in neutral and experimental Coxsackie virus infections. J. Immunol. 100:99-106.

126. Schnurr, D. P., and N. J. Schmidt. 1984. Persistent infection of mouse fibroblasts with coxsackievirus. Arch. Virol. 81:91101.

127. Schultheiss, H. P., K. Schulze, U. Kuhl, G. Ulrich, and M. Klingenberg. 1987. The ADP/ATP carrier as a mitochondrial auto-antigen-facts and perspectives. Ann. N.Y. Acad. Sci. 448:44-68.

127a.Schultheiss, H. P., G. Ulrich, I. Janda, U. Kuhl, and M. Morad. 1988. Antibody-mediated enhancement of calcium permeability in cardiac myocytes. J. Exp. Med. 168:2105-2120.

128. Schultz, M., and R. L. Crowell. 1983. Eclipse of coxsackievirus infectivity; the restrictive event for a non-fusing myogenic cell line. J. Gen. Virol. 64:1725.

129. Shepherd, V. L., Y. C. Lee, P. H. Schlesinger, and P. D. Stahl. 1981. L-fucose-terminated glycoconjugates are recognized by pinocytosis receptors on macrophages. Proc. Natl. Acad. Sci. USA 78:1019-1022.

130. Smith, H. 1977. Host and tissue specificities in virus infections of animals, p. 1-46. In G. Poste (ed.), Virus infection and the cell surface. Elsevier/North-Holland Publishing Co., Amsterdam.

131. Smith, W. G. 1970. Coxsackie B myopericarditis in adults. Am. Heart J. 80:34-46.

132. Somerville, W. 1972. Postcarditic myocardiopathy. Postgrad. Med. J. 48:746-749.

133. Stahl, P. D., and S. Gordon. 1982. Expression of mannosylfucosyl receptor for endocytosis on cultured primary macrophages and their hybrids. J. Cell Biol. 93:49-56.

134. Steere, A. C., R. L. Grodzicki, A. N. Kornblatt, J. E. Craft, A. G. Barbour, W. Burgdorfer, G. P. Schmid, E. Johnson, and S. E. Malawista. 1983. The spirochetal etiology Lyme disease. N. Engl. J. Med. 308:733-740.

135. Sundar, S., B. Shyam, A. K. Gulathi, and P. N. Somani. 1984. Coxsackie A viral carditis in eastern India. J. Assoc. Physicians India 12:501-503.

136. Sutton, G. C., H. B. Harding, and R. P. Trueheart. 1967. Coxsackie B4 myocarditis in an adult: successful isolation of virus from ventricular myocardium. Aerospace Med. 38:66-69.

137. Towbin, H., G. Rosenfelder, J. Wieslander, J. L. Avila, M. Rajas, A. Szarfman, K. Esser, H. Novack, and R. Templ. 1987. Circulating antibodies to mouse laminin in Chagas disease, American cutaneous leishmaniasis and normal individuals recognize terminal galactosyl ( $\alpha$ 1-3)-galactose epitopes. J. Exp. Med. 166:419-427.

138. Townsend, A. R. M., J. Bastin, K. Gould, and G. G. Brownlee. 1986. Cytotoxic $\mathrm{T}$ lymphocytes recognize influenza haemagglutinin that lacks a signal sequence. Nature (London) 324: 575-577.

139. Van Crevelv, S., and H. De Jager. 1956. Myocarditis in newborns, caused by coxsackie virus: clinical \& pathologic data. Ann. Pediatr. 187:100-112.

140. Virchow, R. L. K. 1858. Die Cellullarpathologie in ihrer Begrundung auf physiologische und pathologische Gewebelehre. A. Hirschwald, Berlin.

140a.Von Kreuter, B. F., M. Sadigursky, and C. A. Santos-Buch. 1988. Complementary surface epitopes, myotropic adhesion and active grip in Trypanosoma cruzi-host cell recognition. Mol. Biochem. Parasitol. 30:197-208.

141. Wagner, H., A. Starzinski-Powitz, H. Jung, and M. Rollinghoff. 1977. Induction of I region-restricted hapten-specific cytotoxic T lymphocytes. J. Immunol. 119:1365-1368.

142. Weigle, W. O. 1980. Analysis of autoimmunity through experimental models of thyroiditis and allergic encephalomyelitis. Adv. Immunol. 30:159-273.

143. Weinberg, M., E. H. Fell, and J. Lynfield. 1958. Diagnostic biopsy of the pericardium and myocardium. AMA Arch. Surg. 76:825-829.

144. Wenger, N. K. 1968. Infectious myocarditis. Postgrad. Med. 44:105-112.

145. Wilson, F. M., Q. R. Miranda, J. L. Chason, and A. M. Lerner. 
1969. Residual pathologic changes following murine coxsackie A and B myocarditis. Am. J. Pathol. 55:253-265.

146. Woodruff, J. F. 1979. Lack of correlation between neutralizing antibody production and suppression of coxsackievirus B-3 replication in target organs: evidence for involvement of mononuclear inflammatory cells in defense. J. Immunol. 123:31-36.

147. Woodruff, J. F. 1980. Viral myocarditis. Am. J. Pathol. 101: 425-483.

148. Woodruff, J. F., and J. J. Woodruff. 1974. Involvement of T lymphocytes in the pathogenesis of Coxsackievirus B3 heart disease. J. Immunol. 113:1726-1734.

149. Yasuda, T., I. F. Palacios, G. W. Dec, J. T. Fallon, H. K. Gold,
R. C. Leinback, H. W. Strauss, B. A. Knaw, and E. Haber. 1987. Indium-111 monoclonal antimyosin imaging in the diagnosis of acute myocarditis. Circulation 76:306-311.

150. Zee-Cheng, C., C. C. Tasi, D. C. Palmer, J. E. Codd, D. G. Pennington, and G. A. Williams. 1984. High incidences of myocarditis by endomyocardial biopsy in patients with idiopathic congestive cardiomyopathy. J. Am. Coll. Cardiol. 3: 63-70.

151. Zeichhardt, H., K. Wetz, P. Willingman, and K. Habermehl. 1985. Entry of poliovirus type 1 and mouse Elberfeld virus into HEp-2 cells: receptor mediated endocytosis and endosomal or lysosomal uncoating. J. Gen. Virol. 66:483-492. 